\title{
PENGGUNAAN COMPLETE FEED BERBASIS JERAMI PADI FERMENTASI PADA SAPI AUSTRALIAN COMMERCIAL CROSS TERHADAP KONSUMSI NUTRIEN DAN PERTAMBAHAN BOBOT BADAN HARIAN
}

\author{
Ali Agus, Bambang Suwignyo, dan Ristianto Utomo'
}

\begin{abstract}
INTISARI
Tujuan penelitian ini adalah untuk mengetahui penggunaan Complete Feed (CF) berbasis jerami padi fermentasi (JPF) terhadap konsumsi nutrien dan pertambahan bobot badan harian (PBBH). Sejumlah 36 ekor sapi Australian Commercial Cross (ACC) Steer berat badan awal 310 $330 \mathrm{~kg}$, umur 1,5 2 tahun dibagi secara acak dalam 6 flok dan setiap flok berisi 6 ekor. Ransum CF diberikan 3\% BB (terdiri atas konsentrat $75 \%$ dan JPF 25\%), sedangkan ransum konvensional (KF) sebagai kontrol berupa konsentrat (K) $2 \%$ BB dan JPF diberikan secara ad libitum. Formulasi Complete feed disusun sesuai dengan kebutuhan nutrisi untuk ternak potong sebagaimana direkomendasikan oleh NRC (1984). Air minum diberikan ad libitum. Lama penelitian 12 minggu dengan waktu adaptasi pakan selama 10 hari. Pakan diberikan dua kali, pagi jam 08.00 dan sore jam 15.00. Penimbangan sapi setiap dua minggu sekali. Data konsumsi pakan diambil setiap hari dan dikomposit secara kolektif pada setiap flok setiap minggu kemudian dilakukan analisis dengan uji Ttest. Hasil penelitian menunjukkan bahwa total konsumsi pakan $(\mathrm{kg}) \mathrm{CF}$ vs KF untuk BK $(9,5$ vs 9,4$)$ dan $\mathrm{BO}(9,5$ vs 9,6$)$ keduanya tidak berbeda dan konsumsi $\mathrm{PK}(870$ vs $806 \mathrm{~g})$ berbeda nyata $(\mathrm{P}<0,05)$ dengan rerata konsumsi dalam persen $\mathrm{BB}$ cenderung lebih rendah ( $\mathrm{P}=0,09)$ pada $\mathrm{CF}(2,6 \%$ vs $2,7 \%)$. Pengaruh pakan $\mathrm{CF}$ pada $\mathrm{PBBH}(1,03$ vs 0,$86 ; \mathrm{P}=0,07)$ dan konversi pakan $(9,6$ vs 11,4$)$ menunjukkan lebih baik daripada KF. Secara umum pakan CF menunjukkan penampilan produksi yang lebih baik daripada KF sehingga CF prospektif bila digunakan dalam usaha feedlot dengan menggunakan sapi ACC.
\end{abstract}

(Kata kunci : Complete feed, Jerami padi fermentasi, Australian Commercial Cross, Pertambahan bobot badan harian).

'Fakultas Peternakan Universitas Gadjah Mada, Yogyakarta. 


\title{
UTILIZATION OF COMPLETE FEED BASED ON FERMENTED RICE STRAW FOR AUSTRALIAN COMMERCIAL CROSS STEER ON THE NUTRIENT INTAKE AND AVERAGE DAILY GAIN
}

\begin{abstract}
The objectives of this research was to study the utilization of complete feed (CF) based on fermented rice straw (FRS) for Australian Commercial Cross (ACC) steer on the nutrient intake and average daily gain (ADG). Thirty six steer of $1.5-2$ year old $(310-330 \mathrm{~kg})$ were devided into two groups (treatment vs control) 3 flocks consisting of 6 head/flock were allocated for each group. To the animals in treatment group were offered $3 \% \mathrm{BW}$ of CF (consisting concentrate $75 \%$ and FRS $25 \%$ ), while in control group animal received conventional feed (KF) which contained $2 \%$ BW of concentrate and FRS ad libitum. Complete feed was formulated to cover the nutrient requirement of beef cattle as recommended by NRC (1984). The water was available ad libitum. Before feeding treatment ( 3 month) started, the animals were adapted on experimental feed for 10 days. Feed was given twice a day $(08.00 \mathrm{p} . \mathrm{m}$. and $15.00 \mathrm{p} . \mathrm{m}$.). BW was controlled every two weeks. The data of intake were controlled everyday. All data collected were analyzed by T-test. The DM ( $9.5 \mathrm{vs} 9.4 \mathrm{~kg})$ and OM $(9.5 \mathrm{vs} 9.6 \mathrm{~kg})$ intake in both treatments were not significantly different; while for CP intake in group CF was higher $(\mathrm{P}<0.05)$ than in $\mathrm{KF}$ group $(870 \mathrm{vs} 806 \mathrm{~g})$. The effect of CF on ADG $(1,03$ vs 0,$86 ; \mathrm{P}<$ $0,07)$ and FCR $(9,6$ vs 11,4$)$ was better than KF. It could be concluded that the use of CF based on FRS gave a better result if compared to the use of KF on ACC steer performance.
\end{abstract}

(Key words : Complete feed, Fermented rice straw, Australian Commercial Cross, Average daily gain).

\section{Pendahuluan}

Sapi potong merupakan komoditas penting dalam pemenuhan kebutuhan daging masyarakat yaitu menyumbang $23,9 \%$ dari total konsumen daging nasional pada tahun 1998 (Pambudy, 2000). Kebutuhan daging nasional mendorong setiap tahunnya Indonesia impor tak kurang dari 380.000 ekor sapi dan 25 juta kg daging beku (Harmadji, 1999). Jenis sapi yang didatangkan mayoritas adalah Brahman Cross yang lebih dikenal dalam perdagangan sebagai sapi Australian Commercial Cross (ACC). Dewasa ini sedang dikembangkan teknologi dalam dunia pakan ternak potong yaitu yang disebut dengan complete feed (CF). Complete feed adalah makanan yang cukup gizi untuk hewan tertentu di dalam tingkat fisiologi tertentu dibentuk/dicampur untuk diberikan sebagai satusatunya makanan dan mampu dalam merawat hidup pokok atau produksi (atau keduanya) tanpa tambahan pakan/subtansi lain kecuali air (Hartadi et al., 1997). Pemanfaatan limbah pertanian seperti jerami padi sebagai pakan basal adalah upaya untuk meningkatkan efisiensi usaha dengan menekan biaya dari pakan. Jerami padi menjadi alternatif pakan sumber serat bagi ruminansia karena masih memiliki nilai nutrien yang baik dibanding jerami yang lain. Kendala pemanfaatan jerami adalah pada kualitas yang disebabkan adanya ikatan pada karbohidrat bersamaan dengan lignin yang jumlahnya mencapai $20120 \mathrm{~g} / \mathrm{kg} \mathrm{BK}$, sehingga selulosa yang dapat dicerna kurang dari $60 \%$ (McDonald, 2002). Perlakuan teknologi seperti fermentasi dan atau amoniasi dapat meningkatkan nilai nutrisinya selain bersifat mengawetkan bahan pakan tersebut.

Sektor usaha yang dapat memanfaatkan jerami padi adalah usaha sapi potong (Feedlot) baik di peternakan rakyat maupun industri peternakan. Akan tetapi penelitian tentang CF di Indonesia khususnya untuk sapi potong masih terbatas. Oleh karena itu perlu adanya pengkajian melalui penelitian efek CF terhadap penampilan produksi seperti konsumsi, pertambahan bobot badan harian (PBBH) dan efisiensi secara ekonomis. Tujuan penelitian ini 
adalah untuk mengetahui perbandingan efek Complete Feed (CF) berbasis jerami padi fermentasi terhadap konsumsi nutrien, dan pertambahan bobot badan sapi Australian Commercial Cross (ACC).

\section{Materi dan Metode}

Sapi Australian Commercial Cross (ACC) Steer dengan berat badan awal $310-330$ $\mathrm{kg}$, berumur 1,5 2 tahun sebanyak 36 ekor dibagi secara acak dalam 6 flok (sehingga setiap flok berisi 6 ekor). Pakan yang diberikan ternak berupa $C F$ dan sebagai kontrol adalah KF masingmasing diberikan dua kali, yaitu pagi jam 08.00 dan sore jam 15.00 . Jenis konsentrat $K F$ dan $C F$ berbeda kandungan nutrisinya.

Tabel 1. Komposisi kimia bahan pakan penyusun CF dan KF (Chemical composition of $C F$ and $K F$ ingredients)

\begin{tabular}{|c|c|c|c|c|}
\hline $\begin{array}{l}\text { Jenis bahan pakan } \\
\text { (Feed stuff) }\end{array}$ & $\begin{array}{c}\text { Bahan } \\
\text { organik } \\
(\%)^{\prime} \\
\text { (Organic } \\
\text { matter) }\end{array}$ & $\begin{array}{l}\text { Protein } \\
\text { kasar } \\
(\%)^{1} \\
\text { (Crude } \\
\text { protein) }\end{array}$ & $\begin{array}{c}\text { TDN } \\
(\%) \\
\text { (Total } \\
\text { digestible } \\
\text { nutrient) }\end{array}$ & $\begin{array}{c}\text { Kecernaan } \\
\text { in vitro } \\
(\%)^{2} \\
\text { (In vitro } \\
\text { digestibility) }\end{array}$ \\
\hline $\begin{array}{l}\text { Wheat pollard (BK } 88,4 \% \text { ) } \\
\text { Bungkil kopra (BK } 90,1 \% \text { ) }\end{array}$ & - & 16,7 & $86,0^{4}$ & 79,5 \\
\hline $\begin{array}{l}\text { (Coconut coprah cake) } \\
\text { Kulit kacang (BK } 90,3 \%)\end{array}$ & 84,1 & 14,3 & $73,0^{4}$ & 54,3 \\
\hline $\begin{array}{l}\text { (Peanut hulls) } \\
\text { Dedak padi (BK 91,0\%) }\end{array}$ & 87,6 & 6,3 & $32,1^{3}$ & 12,1 \\
\hline $\begin{array}{l}\text { (Rice bran) } \\
\text { Jagung giling (BK } 90,1 \% \text { ) }\end{array}$ & 85,2 & 8,8 & $70.0^{4}$ & 47,0 \\
\hline $\begin{array}{l}\text { (Conn mill) } \\
\text { Gaplek (BK } 80,7 \%)\end{array}$ & 97,7 & 9,2 & $80.0^{4}$ & - \\
\hline $\begin{array}{l}\text { (Cassava meal) } \\
\text { Onggok (BK } 87,7 \%)\end{array}$ & 97,6 & 2.1 & $86,1^{4}$ & - \\
\hline $\begin{array}{l}\text { (Cassava pomace) } \\
\text { Roti BS (BK } 91,5 \% \text { ) }\end{array}$ & 85,6 & 2.1 & $40,0^{3}$ & 62,6 \\
\hline (BS Biscuit) & 91,4 & 5,1 & $40.7^{3}$ & 72,0 \\
\hline $\begin{array}{l}\text { Analisis dilakukan di Labor } \\
\text { UGM, Yogyakarta (Analize, } \\
\text { Agriculture Technology GM } \\
\text { Analisis (in vitro) dilakukan } \\
\text { (In vitro analysis done in Lo } \\
\text { Yogyakarta). } \\
\text { TDN dicari dengan perhiti } \\
\text { calculated as class feeds forn } \\
\text { Nilai TDN pada tabel (NRC, }\end{array}$ & $\begin{array}{l}\text { um Biokim } \\
\text { Laborator } \\
\text { gyakarta), } \\
\text { ab. Makan } \\
\text { atory of } A \\
\text { n rumus }\end{array}$ & $\begin{array}{l}\text { angan da } \\
\text { Food a } \\
\text { ernak, F } \\
\text { al Nutriti } \\
\text { i kelas }\end{array}$ & $\begin{array}{l}\text { Petemakan } \\
\text { ulty of } \mathrm{An} \\
\text { akan }(\mathrm{Ha}\end{array}$ & $\begin{array}{l}\text { logi Pertanian } \\
y \text {, Faculty of } \\
\text { 4, Yogyakarta } \\
\text { science GMO, } \\
\text { 1997) (TDN }\end{array}$ \\
\hline
\end{tabular}


Ransum KF terdiri dari jerami padi fermentasi + konsentrat komersial dengan pemberian konsentrat sejumlah $2 \% \mathrm{BB}$, sedangkan JPF diberikan secara ad libitum. Konsentrat untuk CF berasal dari unit feed mill Koperasi Peternakan Sarono Makmur Cangkringan (dalam $100 \mathrm{~kg}$ ) terdiri atas bekatul padi (12), onggok (24), gaplek $(4,8)$, bungkil kopra $(6,4)$, kulit kacang (12), roti $(6,4)$, pollard $(7,2)$, jagung kuning giling $(19,5)$, mollases (4), $\operatorname{Biofad}^{*}(0,5)$ $\mathrm{NaCl}(1,6)$, dan calsid $(1,6)$. Air minum diberikan secara ad libitum. Fermentasi jerami padi dengan menggunakan Biofad ${ }^{*}$ (Agus et al., 1999). Kandungan nutrisi bahan pakan penyusun CF dan KF dapat dilihat pada Tabel 1 dan Tabel 2.

Pemeliharaan ternak selama penelitian dilakukan di perusahaan peternakan Koperasi Majlis Taklim Widodo Makmur, Bayat, Klaten, Jawa Tengah dalam jangka waktu 3 bulan (12 minggu) termasuk pemotongan dengan masa adaptasi ternak terhadap pakan selama 10 hari. Pemberian pakan dan sisa ditimbang setiap hari dengan timbangan merk Salter dengan kepekaan
$1 \mathrm{~kg}$ dan merk Lion Star dengan kepekaan 0,025 $\mathrm{kg}$ kemudian dicatat. Pengambilan sampel sisa pakan kira-kira $10 \%$ dari sisa. Sampel sisa dikomposit pada setiap satu minggu (7 hari) koleksi, kemudian dianalisis di laboratorium. Metode komposit sampel dengan cara sampel pada kandang perlakuan yang sama dalam seminggu (7 kali sampling) dikelompokkan menjadi satu, kemudian dicampur dan diambil sebagian (mixing and quartering) sebagai sampel akhir.

Penimbangan sapi pertama kali dilakukan sebelum sapi dimasukkan ke kandang, yaitu pada awal penelitian. Penimbangan selanjutnya secara berkala setiap dua minggu sekali dengan timbangan ternak (digital) merk Rougweight dengan kepekaan 0,1 kg. Kenaikan berat badan di catat per individu dan kemudian dirata-rata secara kolektif pada setiap kelompok ternak perlakuan. Setiap kali penimbangan dilakukan pada pagi hari jam 07.30 sebelum sapi diberi makan.

Tabel 2. Komposisi kimia bahan pakan CF dan KF serta jerami padi (Chemical composition of $C F, K F$ diet, and rice straw)

\begin{tabular}{|c|c|c|c|c|c|c|}
\hline $\begin{array}{l}\text { Jenis bahan pakan } \\
\text { (Feed stuff) }\end{array}$ & $\begin{array}{c}\text { Bahan } \\
\text { organik } \\
(\%)^{1} \\
\text { (Organic } \\
\text { Matter) }\end{array}$ & $\begin{array}{l}\text { Protein } \\
\text { kasar } \\
(\%)^{1} \\
\text { (Crude } \\
\text { protein) }\end{array}$ & $\begin{array}{l}\text { Serat } \\
\text { kasar } \\
(\%)^{1} \\
\text { (Crude } \\
\text { fiber) }\end{array}$ & $\begin{array}{l}\text { Lemak } \\
\text { kasar } \\
(\%)^{1} \\
\text { (Extract } \\
\text { ether) }\end{array}$ & $\begin{array}{c}\text { TDN } \\
(\%)^{3} \\
\text { (Total } \\
\text { digestible } \\
\text { nutrient) }\end{array}$ & $\begin{array}{c}\text { Kecernaan } \\
\text { In vitro } \\
(\%)^{2} \\
\text { (In vitro } \\
\text { digestibility) }\end{array}$ \\
\hline $\begin{array}{l}\text { Konsentrat KF (BK 85,2\%) } \\
\text { (Concentrate of conventional feed) }\end{array}$ & 86,4 & 7,4 & 25,9 & 6,8 & 52,9 & 64,9 \\
\hline $\begin{array}{l}\text { Konsentrat CF (BK 88,3\%) } \\
\text { (Concentrate of complete feed) }\end{array}$ & 89,6 & 8,1 & 28,4 & 1,9 & 57,9 & 65,0 \\
\hline $\begin{array}{l}\text { Jerami padi fermentasi (BK } 84,5 \% \text { ) } \\
\text { (Fermented rice straw) } \\
\text { Jerami padi non fermentasi (BK } \\
64,0 \% \text { ) (Non fermentated rice }\end{array}$ & 79,1 & 7,7 & 32,2 & 2,4 & 52,6 & 25,2 \\
\hline & 81,0 & 5,4 & 29,1 & 1,7 & 44,5 & - \\
\hline
\end{tabular}

'Analisis dilakukan di Lab. Biokimia Pangan dan Gizi, Fak. Teknologi Pertanian UGM (Analized in Laboratory of Food and Nutritional Biochemistry, Faculty of Agriculture Technology GMU, Yogyakarta).

2 Analisis (in vitro) dilakukan di Lab. Makanan Ternak Fakultas Peternakan GMU, Yogyakarta (In vitro analized in Laboratory of Animal Feed, Faculty of Animal Science GMU, Yogyakarta).

${ }^{3}$ TDN dicari dengan perhitungan rumus sesuai kelas bahan pakan (Hartadi, 1997) (TDN calculated as class feeds formula (Hartadi, 1997)). 
Analisis sampel pakan dilakukan di Laboratorium Makanan Ternak, Jurusan Nutrisi dan Makanan Ternak Fakultas Peternakan Universitas Gadjah Mada (UGM) Yogyakarta serta Laboratorium Biokimia Bahan Pangan dan Gizi Fakultas Teknologi Pertanian UGM. Variabel yang diamati adalah komposisi kimia ransum, konsumsi pakan, $\mathrm{PBBH}$, income over feed cost (IOFC), dan feed conversion ratio (FCR). Seluruh data yang terkumpul kemudian dilakukan uji beda dengan analisis T-test dengan program komputer Microsoft Excel.

\section{Hasil dan Pembahasan}

\section{Konsumsi dan pertumbuhan}

Perbedaan jumlah nutrisi yang dapat dikonsumsi oleh ternak dapat diamati dari konsumsi BK, BO, PK, dan TDN. Konsumsi pakan meningkat (pada CF dan KF) seiring dengan pertambahan berat badan (BB) karena terjadinya pertambahan BB menyebabkan peningkatan kebutuhan nutrisi yang kemudian mendorong ternak untuk mengkonsumsi pakan lebih besar/banyak. Pada variabel konsumsi BK jumlah rerata total konsumsi $\mathrm{CF}$ dan KF relatif sama $(9,5 \mathrm{~kg}$ vs $9,4 \mathrm{~kg})$ dalam $\mathrm{g} / \mathrm{kg}$ BB setara dengan 26,3 .

Hasil penelitian lain dilaporkan Ngadiyono (1995), menyatakan bahwa sapi BX dan sapi ACC keduanya dengan BB $314,61 \pm$ $21,25 \mathrm{~kg}$ yang diberi pakan rumput raja dan konsentrat $(15: 85)$ diketahui konsumsi BK 7,88 vs 8,75 (kg/ekor/hari); $5,18 \mathrm{~kg}$ (Isnainiyati, 2001) pada sapi PO (BB $185 \mathrm{~kg}$ ) yang diberi pakan JPF dan konsentrat; 8,15 (Suparman, 1997) pada sapi BX (BB $310,14 \mathrm{~kg}$ ) dengan pakan konsentrat dan rumput gajah $(80: 20)$. Jumlah konsumsi pakan pada ternak dapat dilihat pada Tabel 3 .

Pada variabel konsumsi dalam persentase berat badan (BB), total konsumsi pakan CF dan $\mathrm{KF}$ hampir sama, meskipun KF sedikit lebih tinggi $(\mathrm{P}<0,09)$ daripada $\mathrm{CF}$. Ternak mampu mengkonsumsi pakan CF maupun $\mathrm{KF}$ antara $2,5 \% 2,8 \%$ dengan rata-rata $\mathrm{CF} 2,6 \%$ dan $\mathrm{KF}$ $2,7 \%$ (Tabel 3). Keadaan ini hampir sama dengan penelitian terdahulu bahwasanya konsumsi BK dalam persentase BB ternak bisa mencapai 2,5 2,7\% (Pond et al., 1995); 3\% (Anonimus 1998); 2,44\% (Tuswati, 1998); 2,67\% (Suparman, 1997). Pada ternak ruminansia, jumlah konsumsi dalam persentase $\mathrm{BB}$ akan memiliki hubungan erat dengan kapasitas saluran pencernaan terutama rumen (Pond et al., 1995).

Pada variabel konsumsi $\mathrm{BO}$, secara rerata total konsumsi CF relatif sama dengan $\mathrm{KF}(9,5 \mathrm{vs}$ $9,6 \mathrm{~kg}$ ) dalam $\mathrm{g} / \mathrm{kg}$ BB setara dengan 26,3 vs 26,9. Kebutuhan nutrisi di dalam tubuh pada ternak yang berbeda kondisinya juga menyebabkan perbedaan perilaku konsumsi.

Rerata total konsumsi PK pakan KF lebih rendah $(\mathrm{P}<0,05)$ dibanding pakan CF yaitu 870 vs $806 \mathrm{~g} / \mathrm{ek} / \mathrm{hari}$ (2,5 vs $2,3 \mathrm{~g} / \mathrm{kg} \mathrm{BB}$ ). Angka ini lebih rendah dari hasil penelitian Suparman (1997) pada sapi BX dengan pakan konsentrat dan rumput gajah $(80: 20)$ yaitu $1,14 \mathrm{~kg}$. Pond et al. (1995) menyatakan bahwa protein termasuk bahan organik yang sangat penting bagi organisme. Protein sangat diperlukan bagi pertumbuhan ternak. Ternak jantan kastrasi (steer) dengan BB $300 \mathrm{~kg}$ dengan target ADG 1 $\mathrm{kg}$ diperlukan konsumsi protein sebesar $0,76 \mathrm{~kg}$ dan $0,82 \mathrm{~kg}$ untuk steer dengan BB $400 \mathrm{~kg}$ (NRC, 1984). Pada penelitian kali ini konsumsi protein adalah 806 vs $870 \mathrm{~g}$ dengan BB awal sapi yaitu 315,4 vs $316,1 \mathrm{~kg}$ dan berat akhir 379,6 vs 390,1 . Jumlah konsumsi protein tersebut sebenarnya cukup untuk memproduksi ADG $1 \mathrm{~kg}$, namun demikian pada kenyataannya rerata ADG bervariasi yaitu 0,89 pada $\mathrm{KF}$ dan 1,03 pada CF.

Ternak memenuhi kebutuhan hidupnya dengan mengkonsumsi ransum yang ada di sekitarnya. Pakan CF diberikan sesuai kebutuhannya dalam jumlah tertentu $(3 \% \mathrm{BB})$ dan tetap antara proporsi JPF dan K (25:75), sehingga tidak memungkinkan bagi ternak untuk menambah konsumsi jika ransum yang diberikan belum memenuhi kebutuhannya. 
Tabel 3. Konsumsi BK, BO, PK, TDN, dan persentase berat badan (Nutrient intake for DM, OM, CP. TDN and percent of body weight)

\begin{tabular}{|c|c|c|c|c|}
\hline \multirow[t]{2}{*}{ Variabel (Variable) } & \multicolumn{2}{|c|}{$\begin{array}{l}\text { Nilai rerata } \\
\text { (Average) }\end{array}$} & \multirow{2}{*}{$\begin{array}{c}\text { RSD } \\
\text { (Residual standard } \\
\text { deviation) }\end{array}$} & \multirow[t]{2}{*}{$\begin{array}{l}\text { Signifikansi } \\
\text { (Signification) }\end{array}$} \\
\hline & $\mathrm{CF}^{\prime}$ & $\mathrm{KF}$ & & \\
\hline \multicolumn{5}{|c|}{ Bahan kering (BK) kg/ekor/hari (Dry matter ( $k g / h e a d$ day)) } \\
\hline Konsentrat (Concentrate) & 7,2 & 6.4 & 0.45 & * \\
\hline JPF (Fermented rice straw) & 2,3 & 3,0 & 0,44 & $\mathrm{P}=0,08$ \\
\hline Total (Konsentrat + JPF) & & & & \\
\hline (Total (Concentrate + FRS)) & 9,5 & 9,4 & 0,26 & ns \\
\hline \multicolumn{5}{|c|}{ Bahan organik (BO) $\mathrm{kg} / \mathrm{ekor} / \mathrm{har}$ (Organic matter ( $\mathrm{kg} / \mathrm{head} /$ day)) } \\
\hline Konsentrat (Concentrate) & 7,3 & 6,5 & 0,55 & * \\
\hline JPF (Fermented rice straw) & 2,2 & 3,1 & 0.46 & $\mathrm{P}=0,06$ \\
\hline Total (Konsentrat + JPF) & & & & \\
\hline (Total (Concentrate + FRS)) & 9,5 & 9,6 & 0,23 & ns \\
\hline \multicolumn{5}{|c|}{ Protein kasar (PK) g/ekot/hari (Crude protein (g/head/day)) } \\
\hline Konsentrat (Concentrate) & 668 & 554 & 0,06 & ** \\
\hline JPF (Fermented rice straw) & 214 & 265 & 0,03 & ns \\
\hline $\begin{array}{l}\text { Total (Konsentrat }+ \text { JPF }) \\
\text { (Total (Concentrate }+ \text { FRS)) }\end{array}$ & 870 & 806 & 0,04 & $*$ \\
\hline Rerata BK \% Berat badan & & & & \\
\hline (Average \% dry matter body weight) & 2,6 & 2,7 & 0,001 & $\mathrm{P}=0,09$ \\
\hline \multicolumn{5}{|c|}{ TDN (kg/ekor/hari) (Total digestible nutrient (kg/head/day)) } \\
\hline Konsentrat (Concentrate) & 4,69 & 3,95 & 0,43 & ** \\
\hline JPF (Fermented rice straw) & $\mathrm{I}, 15$ & 1,49 & 0,24 & $\mathrm{P}=0,07$ \\
\hline $\begin{array}{l}\text { Total (Konsentrat + JPF) } \\
\text { (Total (Concentrate }+ \text { FRS)) }\end{array}$ & & 5.44 & 0,26 & * \\
\hline
\end{tabular}

' rasio JPF/ konsentrat pada ransum: $25 / 75$ (JPF/consentrate ratio in diet: $25 / 75$ ).

"* non significant.

* Berbeda nyata $(P<0,05)$ (Significant differences $(P<0.05))$.

** Berbeda sangat nyata $(\mathrm{P}<0,01)$ (High significant differences $(P<0.01)$ ).

Pakan KF hanya pada konsentrat yang diberikan tetap $(2 \% \mathrm{BB})$, sedangkan JPF diberikan ad libitum. Ketika konsentrat belum memenuhi kebutuhannya maka ternak akan mengkonsumsi JPF dalam jumlah banyak. Oleh karena itu konsumsi JPF baik untuk BK, BO maupun PK jumlahnya lebih tinggi pada pakan KF daripada $\mathrm{CF}(\mathrm{P}<0,05)$, akan tetapi total konsumsinya relatif sama (Tabel 3). Perbedaan jumlah nutrisi yang dapat dikonsumsi oleh ternak dapat diamati dari konsumsi BK, BO dan PK. Jumlah konsumsi pakan pada ternak dapat dilihat pada Tabel 3.

Pertumbuhan diikuti dengan peningkatan berat badan fungsi atau tujuan dari kerangka.
Pada penelitian ini berat badan diukur dengan penimbangan ternak dan angka PBBH adalah nilai slope suatu regresi linier dari setiap titik penimbangan berbanding waktu. Pada akhir pemeliharaan $\mathrm{BB}$ ternak dengan pakan $\mathrm{CF}$ adalah $390,1 \mathrm{~kg}$, sedangkan ternak dengan pakan $\mathrm{KF}$ sebesar $379,6 \mathrm{~kg}$. Jika dilihat dari nilai ADG, ternak dengan pakan $\mathrm{CF}$ mencapai $\mathrm{ADG}$ tertinggi pada minggu ke-8 sebesar 1,07, sedangkan pada pakan KF pada minggu ke-6 sebesar 0,90 . Rata-rata ADG ternak dengan pakan CF adalah $1,03 \mathrm{~kg}$ yaitu cenderung lebih tinggi $(\mathrm{P}=0,07)$ daripada pakan KF yang sebesar $0,86 \mathrm{~kg}$ (Tabel 5). 
Tabe1 4. Konsumsi pakan protein kasar dan total digestible nutrient (Crude protein and total digestible nutrient intake)

\begin{tabular}{|c|c|c|c|c|}
\hline \multirow[t]{2}{*}{ Variabel (Variable) } & \multicolumn{2}{|c|}{$\begin{array}{l}\text { Nilai rerata } \\
\text { (Average) }\end{array}$} & \multirow{2}{*}{$\begin{array}{c}\text { RSD } \\
\begin{array}{c}\text { (Residual standard } \\
\text { deviation) }\end{array} \\
\end{array}$} & \multirow[t]{2}{*}{$\begin{array}{r}\text { Signifikansi } \\
\text { (Signification) }\end{array}$} \\
\hline & $\mathrm{CF}^{1}$ & $\mathrm{KF}$ & & \\
\hline \multicolumn{5}{|l|}{$\begin{array}{l}\text { Protein kasar }(\mathrm{PK}) \mathrm{g} / \mathrm{ekot} / \mathrm{hari} \\
\text { (Crude protein }(\mathrm{g} / \text { head/day }) \text { ) }\end{array}$} \\
\hline Konsentrat (Concentrate) & 668 & 554 & 0,06 & $* *$ \\
\hline $\begin{array}{l}\text { JPF (Fermented rice straw) } \\
\text { Total (Konsentrat }+ \text { JPF) }\end{array}$ & 214 & 265 & 0,03 & ns \\
\hline $\begin{array}{l}\quad(\text { Total }(\text { Concentrate }+ \text { FRS })) \\
\text { TDN - BK }(\mathrm{g}) \\
\text { (Total digestible nutrient }- \text { dry mat }\end{array}$ & 870 & 806 & 0,04 & * \\
\hline Konsentrat (Concentrate) & 4,50 & 3,73 & 0,45 & ** \\
\hline $\begin{array}{l}\text { JPF (Fermented rice straw) } \\
\text { Total (Konsentrat }+ \text { JPF) }\end{array}$ & 1,15 & 1,49 & 0,24 & $P=0,07$ \\
\hline (Total (Concentrate + FRS)) & 5,65 & 5,21 & 0,28 & - \\
\hline
\end{tabular}

${ }^{1}$ rasio JPF/konsentrat pada ransum : $25 / 75$ (FRS/concentrate ratio in diet : $25 / 75$ ).

" non significant.

* Berbeda nyata $(\mathrm{P}<0,05)$ (Significant differences $(P<0.05)$ ).

** Berbeda sangat nyata $(\mathrm{P}<0,01)$. (High significant differences $(P<0.01)$ ).

Hasil penelitian ini lebih rendah jika dibanding dengan penelitian Tuswati (1998) pada sapi ACC dengan pakan rumput raja dan konsentrat (20: 80), yaitu dihasilkan ADG sebesar $0,99 \mathrm{~kg}$. Akan tetapi hasil ini lebih tinggi dari penelitian Ngadiyono (1995) pada sapi BX dan sapi ACC dengan pakan rumput raja dan konsentrat $(15: 85)$ dengan hasil ADG sebesar 0,78 dan $0,82 \mathrm{~kg}$.

Dengan memperhatikan jumlah konsumsi PK pada CF dan KF ( 0,9 vs 0,8$)$, maka ADG yang dicapai dengan pakan CF adalah menunjukkan prestasi lebih baik daripada pakan $\mathrm{KF}$. Secara umum pakan CF memberikan hasil ADG yang lebih tinggi daripada KF. Hal ini kemungkinan terkait dengan jumlah konsumsi protein dan TDN (Tabel 4) yaitu konsumsi protein dan TDN pakan CF lebih tinggi daripada $\mathrm{KF}$, sebagaimana yang dinyatakan oleh McDonald et al. (2002) bahwa pertumbuhan ternak dikontrol oleh konsumsi nutrien khususnya konsumsi energi. Coleman et al. (1995), menyatakan bahwa naik turunnya ADG sangat dipengaruhi oleh tinggi rendahnya konsumsi pakan, naiknya konsumsi dapat meningkatkan $\mathrm{ADG}$ dan rendahnya konsumsi dapat menurunkan ADG. Nilai rerata ADG dan berat badan dapat dilihat pada Tabel 5 .

Angka berat badan (BB) dan imbangan konsentrat/total (K/Tot) dalam BK secara periodik dari minggu ke-1 sampai minggu ke-12 dilihat pada Tabel 6.

\section{Kesimpulan dan Saran}

Pada sapi ACC steer yang menggunakan JPF sebagai sumber serat, pemberian pakan KF dengan konsentrat yang dibeli di pasaran dapat mencapai $\mathrm{ADG} 0,86$ tetapi dengan pemberian kualitas konsentrat yang diformulasikan dalam CF dapat mencapai ADG $1,03 \mathrm{~kg}$ dengan angka FCR 9,6 pada CF dan 11,4 pada KF. Pertumbuhan ternak mencapai optimal sampai pada minggu ke-8 (CF) dan minggu ke-6 (KF) pemeliharaan dan setelahnya efisiensi akan menurun. Dengan memperhatikan kinerja produksi pada variabel average daily gain dan berat badan akhir. Sapi jenis ACC steer dengan diberikan perlakuan pakan complete feed (CF) berbasis JPF menunjukkan penampilan lebih baik daripada konvensional feed (KF) pada variabel PBBH. 
Tabel 5 . Rerata berat badan dan average daily gain

(Average ofbody weight and average daily gain)

\begin{tabular}{|c|c|c|c|c|}
\hline \multirow{2}{*}{ Variabel (Variable) } & \multicolumn{2}{|c|}{ Nilai rerata (Average) } & \multirow{2}{*}{ RSD } & \multirow{2}{*}{$\begin{array}{c}\text { Signifikansi } \\
\text { (Signification) }\end{array}$} \\
\hline & $\mathrm{CF}$ & KF & & \\
\hline BB awal pemeliharaan $(\mathrm{Kg})$ & 316,1 & 315,4 & 24,74 & ns \\
\hline $\begin{array}{l}\text { (Initial body weight }(\mathrm{Kg}) \text { ) } \\
\text { BB akhir pe meliharaan }(\mathrm{Kg}) \\
\text { (Final body weight }(\mathrm{Kg}) \text { ) }\end{array}$ & 390,1 & 379,6 & 28,52 & ns \\
\hline (Average daily gain, $\mathrm{ADG}(\mathrm{Kg})$ ) & 1,03 & 0,86 & 0,26 & $\mathrm{P}=0,07$ \\
\hline
\end{tabular}

${ }^{\mathrm{nt}}$ non significant

* $\mathrm{P}<0,05$

CF (Complete Feed); RSD (Residual standard deviation)

KF : Pakan konvensional (Conventional feed).

CF: Pakan lengkap (Completefeed).

Tabel 6. Berat badan dan imbangan konsentrat/total (K/Tot) BK dari minggu ke-1 sampai minggu ke-12 (Body weight and concentrate/total dry matter ratio (C/tot) $I^{\text {st }}$ to $12^{\text {th }}$ week).

\begin{tabular}{|c|c|c|c|c|c|c|c|}
\hline \multirow[t]{2}{*}{$\begin{array}{c}\text { Variabel } \\
\text { (Variable) }\end{array}$} & \multirow[t]{2}{*}{$\begin{array}{l}\text { Perlakuan } \\
\text { (Treatment) }\end{array}$} & \multicolumn{6}{|c|}{$\begin{array}{c}\text { Waktu pemeliharaan (minggu) } \\
\text { (Fattening (week)) }\end{array}$} \\
\hline & & 1 & 4 & 6 & 8 & 10 & 12 \\
\hline Berat badan $(\mathrm{kg})$ & $\mathrm{CF}$ & 316,1 & 341,1 & 355,9 & 368,0 & 384,9 & 390,1 \\
\hline (Body weight (kg)) & $\mathrm{KF}$ & 315,4 & 337,6 & 349,9 & 362,9 & 375,7 & 379,6 \\
\hline Konsentrat/total BK (\%) & $\mathrm{CF}$ & 71,2 & 74,9 & 75,6 & 74,6 & 77,7 & 76,4 \\
\hline (Concentrate/total DM (\%)) & $\mathrm{KF}$ & 63,5 & 67,3 & 69,2 & 68,0 & 68,3 & 70,8 \\
\hline
\end{tabular}

CF (Complete feed); KF : Pakan konvensional (Conventional feed).

\section{Daftar Pustaka}

Agus, A., S. Patmowijoto, B. Suhartanto, dan R. Utomo. 1999. Pengembangan Pakan Ternak Ruminansia di Kabupaten Daerah Tingkat II Blora. Laporan Akhir. Program Kerjasama Badan Perencanaan Daerah Blora dengan Fakultas Peternakan UGM. Yogyakarta.

AOAC. 1975. Official Method on Analyzed of Association of Official Analitical Chemist. $12^{\text {th }}$ ed. Ass, Benjamin Franklin. Washington D.C.

Coleman, S. W., R. H. Gallavan, C. B. Williams, W. A. Phillips, J. D. Volesky, S. Rodriguez, and G. L. Bennett. 1995.
Silage or Limit-Fed Grain Growing Diets for Steer : Growth and Carcass Quality. J. Anim.1Sci. -(73): 26092620.

Hartadi, H., S, Reksohadiprodjo, dan A. D. Tillman. 1997. Tabel Komposisi Pakan untuk Indonesia. Cetakan ke-4. Gadjah Mada Press. Yogyakarta.

Harmadji. 1999. Ilmu Kebijakan Peternakan. Hand Out Kuliah S-1. Fakultas Peternakan Universitas Gadjah Mada. Yogyakarta.

Isnainiyati, N. 2001. Penggunaan Jerami Padi Fermentasi dan Kombinasi Jerami PadiSilase Rumput Raja sebagai Pakan Basal serta Pengaruhnya terhadap Pertambahan Bobot Badan Harian dan Kualitas Daging 
Sapi Peranakan Ongole. Tesis S-2. Pascasarjana Ilmu Peternakan. Universitas Gadjah Mada. Yogyakarta.

Kustantinah., Z, Bachrudin, dan H. Hartadi. 1993. Evaluasi Pakan Berserat. Forum Komunikasi Hasil Penelitian Bidang Peternakan. Yogyakarta. $22 \quad 25$ Nopember 1993.

McDonald, P., R. A. Edwards, J. P. D. Greenhalgh, and C. A. Morgan. 2002. Animal Nutrition. Sixth edition. Prentice Hall. Gosport. London.

Ngadiyono, N. 1995. Pertumbuhan serta Sifatsifat Karkas Daging Sumba Ongole, Brahman Cross, dan Australian Commercial Cross yang Dipelihara Secara Intensif pada Berbagai Bobot Potong. Disertasi S-3. Program Pascasarjana, Institut Pertanian Bogor.

NRC. 1984. Nutrient Requirement of Beef Cattle. $6^{\text {th }}$ rev. ed. National Academy Press. Washington D.C.

Pambudy, R. 2000. Tinjauan Aspek Ekonomi dan Sosial terhadap Konsepsi Intensifikasi Sapi Potong Dalam Mendukung Swasembada Daging 2005 (dari Manajemen Produksi ke
Manajemen Bisnis). Proseding Seminar. Direktorat Jendral Peternakan, Direktorat Bina Produksi Peternakan. Januari 2000. Jakarta.

Pond, W. G., D. C. Church, and K. R Pond. 1995. Basic Animal Nutrition and Feeding. $4^{\text {th }}$ edition. John Wileys and Sons Inc. Canada.

Suparman, P. 1997. Pengaruh Lama Penggemukan dan Puasa sebelum Dipotong terhadap Produksi Karkas dan Karakteristik Fisik Daging Sapi Brahman Cross. Tesis S-2. Pascasarjana Ilmu Peternakan. Universitas Gadjah Mada. Yogyakarta.

Tuswati, S. E. 1998. Pengaruh Frekuensi Pemberian Pakan terhadap Konsumsi Pakan, Kondisi Rumen dan Kinerja Sapi Australian Commercial Cross. Tesis S-2. Pascasarjana Ilmu Peternakan. Universitas Gadjah Mada. Yogyakarta.

Utomo, R. 2003. Penyediaan Pakan di Daerah Tropik : Problematika, Kontinuitas, dan Kualitas. Pidato Pengukuhan Jabatan Guru Besar. Fakultas Peternakan Universitas Gadjah Mada. Yogyakarta. 